\title{
Main intestinal markers associated with the changes in gut architecture and function in piglets after weaning
}

\author{
Lucile Montagne*, Gaëlle Boudry, Christine Favier, Isabelle Le Huërou-Luron, Jean-Paul Lallès \\ and Bernard Sève \\ Unité Mixte de Recherche Systèmes d'Elevage, Nutrition Animale et Humaine, INRA/Agrocampus Rennes, \\ Domaine de la Prise, 35590 Saint-Gilles, France \\ (Received 19 December 2005 - Revised 6 June 2006 - Accepted 4 July 2006)
}

\begin{abstract}
We analysed the spatio-temporal sequence of events concerning the morphology, physiology and ecology of the gut of piglets during the 2 weeks following weaning, in order to provide a limited number of variables that could be relevant markers of the gut post-weaning changes. An experiment was conducted on sixty piglets fasted for $2 \mathrm{~d}$, then administered a weaning diet with a moderate or a high content of wheat using controlled gastric feeding, and slaughtered at different time-points post-weaning. Sixty-nine variables were analysed by principal component analysis. The results showed that the temporal changes induced in the gut by weaning can be divided into two periods: an acute period happening immediately after weaning, followed after day 5 by a more progressive adaptative and maturational phase. The main factors of this adaptation were the refeeding process and the time, while the diet per se had little influence. The villus length, lactase activity, macromolecule fluxes across the jejunum and the plasma cholecystokinin were proposed as markers of the acute phase. The mass of the jejunum, the weight of the pancreas, the content of stomach, the trypsin activity and the theophylline-induced secretion in jejunum were related to the re-feeding. Markers proposed to follow the gut maturation were the maltase activity, the glucose absorption and the basal resistance in the ileum, the lactobacilli and enterococci in the colon, and the $\mathrm{pH}$ of colonic and caecal contents. These markers might be helpful to design suitable diets to limit post-weaning gut disorders in pigs.
\end{abstract}

Weaning piglet: Gut physiology: Principal component analysis

Weaning in the piglet is marked by significant social, environmental and nutritional changes. These changes generally result in a critical period of low voluntary feed intake, during which the pig is adapting to the starter diet (Le Dividich \& Sève, 2000). Immediate post-weaning anorexia results in the alteration of gut integrity and appears to be one of the major aetiologic factors in gut-associated disorders (Hampson, 1994). As reviewed by Vente-Spreeuwenberg \& Beynen (2003) and Lallès et al. (2004), the transient alteration of the gut integrity is characterised by shortened villous length (Pluske et al. 1997), disturbed absorptive-secretory electrolyte and fluid balances, increased mucosal permeability (Miller \& Skadhauge, 1997; Vente-Spreeuwenberg et al. 2001; Boudry et al. 2004), decreased enzymatic activities (Pluske et al. 1997), stimulation of proinflammatory cytokine gene expression (McCracken et al. 1999; Pié et al. 2004), activation of heat shock proteins in the mucosa (David et al. 2000), as well as lowered level of mucins (Lopez-Pedrosa et al. 1998) and goblet cell density (Brown et al. 1988; Nuñez et al. 1996). A 1-2-week adaptative phase to solid diets based on plant ingredients is then observed.

Although the effects of weaning have been extensively investigated in pigs, no integrated study on gut morphology, physiology and ecology covering the 2 weeks following weaning, with details about changes over time, has been reported so far. Integrating the progress of physiological and microbiological events at different sites of the gastrointestinal tract would be relevant to a better understanding of the post-weaning process. This is a first need to promote a rational use of new alternatives to in-feed antibiotics and dietary strategies. Indeed, in connection with the total ban on in-feed antibiotics in the European Union since January 2006, it has become urgent to propose relevant health criteria that could be useful for objective assessment of alternatives to in-feed antibiotics and metals.

The aim of the present work was therefore to investigate the temporal sequence of events concerning the digestive tract characteristics, the digestive enzyme capacities, the mucosal morphology, the mucosal absorptive and secretory capacities, the epithelial barrier function and the bacterial populations, at different sites of the gastrointestinal tract of piglets and during the 2 weeks following weaning. Two diets were formulated to assess possible dietary influences. Analysis of data by principal component analysis (PCA) permits us to have an integrated view of the phenomena occurring at weaning, to reduce the complexity of the dataset and to propose a limited number of variables that might be valuable markers of weaning events.

\footnotetext{
Abbreviations: CCK, cholecystokinin; HRP, horseradish peroxidase; Isc, short-circuit current; PCA, principal component analysis.

* Corresponding author: Dr Lucile Montagne, 65 rue de Saint-Brieuc, CS84215, 35042 Rennes Cedex, France, fax + 33 (0) 223 485900, email montagne@agrocampusrennes.fr
} 


\section{Materials and methods}

\section{Experiment}

Animals and diets. The experimental procedure was conducted in accordance with the French Ministry of Agriculture for the care and use of laboratory animals. Sixty piglets [Pietrain $\times($ Large White $\times$ Landrace $)$ ] obtained from the INRA herd (Saint-Gilles, France) were selected from eighteen litters. Piglets were divided into thirty pairs of weight-matched littermates. The experiment was carried out in six replicates of five pairs of piglets each. Each piglet of a pair was assigned to one of the two weaning diets (Table 1). Both diets were formulated to meet requirements for growth of newly weaning pigs (Sève, 1994) and to be similar in crude protein $(215 \mathrm{~g} / \mathrm{kg} \mathrm{DM})$ and net energy $(10 \mathrm{MJ} / \mathrm{kg} \mathrm{DM})$ content. The formula of diet 1 was similar to the conventional post-weaning diet used in French commercial piggeries. In diet 2, wheat was chosen because it was assumed to induce more diarrhoea in piglets at weaning compared to other cereals like maize or barley $(\mathrm{Qu}-$ emere et al. 1975). Compared to barley, wheat displays a lower digestibility of NSP (Pluske et al. 2001). In addition, the replacement of maltodextrin and whey powder by wheat induced a lower digestibility of protein and energy in diet 2 when

Table 1. Composition of the experimental weaning diets

\begin{tabular}{|c|c|c|}
\hline & Diet 1 & Diet 2 \\
\hline \multicolumn{3}{|l|}{ Ingredient (g/kg air-dried diet) } \\
\hline Wheat & $243 \cdot 1$ & 678.9 \\
\hline Barley & $245 \cdot 0$ & - \\
\hline Soyabean meal & $160 \cdot 0$ & $160 \cdot 0$ \\
\hline Maltodextrin & $40 \cdot 0$ & - \\
\hline Whey powder & $150 \cdot 0$ & - \\
\hline Soluble fish protein concentrate & $82 \cdot 5$ & $83 \cdot 0$ \\
\hline Sunflower oil & $28 \cdot 0$ & $26 \cdot 0$ \\
\hline Calcium carbonate & $15 \cdot 0$ & $18 \cdot 0$ \\
\hline Monocalcium phosphate. $2 \mathrm{H}_{2} \mathrm{O}$ & $20 \cdot 0$ & $22 \cdot 0$ \\
\hline Sodium chloride & - & $2 \cdot 0$ \\
\hline Trace element and vitamin premix ${ }^{*}$ & $5 \cdot 0$ & $5 \cdot 0$ \\
\hline L-Lysine- $\mathrm{HCl}$ & $1 \cdot 3$ & 2.5 \\
\hline DL-Methionine & $8 \cdot 5$ & 0.7 \\
\hline L-Threonine & $1 \cdot 3$ & 1.6 \\
\hline L-Tryptophan & 0.3 & 0.3 \\
\hline \multicolumn{3}{|c|}{ Calculated and chemical analysis (\% or as specified) } \\
\hline Crude protein $(\mathrm{N} \times 6.25)$ & 21.5 & $21 \cdot 3$ \\
\hline \multicolumn{3}{|l|}{ Digestible amino acids† } \\
\hline Lysine & $1 \cdot 2$ & $1 \cdot 2$ \\
\hline Methionine & 0.45 & 0.46 \\
\hline Methionine + cysteine & 0.76 & 0.75 \\
\hline Threonine & 0.82 & 0.81 \\
\hline Tryptophan & 0.23 & 0.23 \\
\hline Digestible energy (MJ/kg) & $14 \cdot 30$ & $14 \cdot 22$ \\
\hline Net energy $(\mathrm{MJ} / \mathrm{kg})$ & $10 \cdot 11$ & $10 \cdot 03$ \\
\hline \multicolumn{3}{|c|}{ 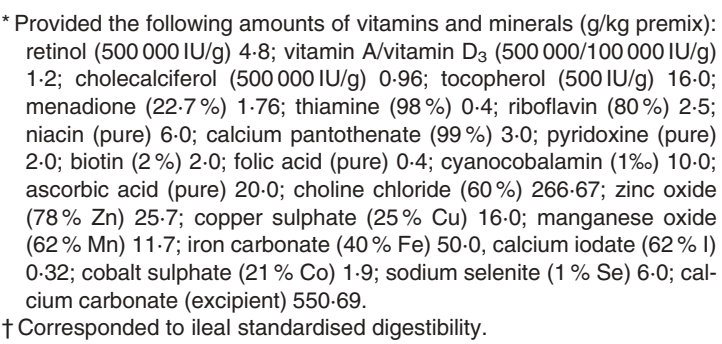 } \\
\hline
\end{tabular}

compared to diet 1 . The diets were prepared as a mash (DM-water, 2:1) before distribution.

The piglets were weaned at $21 \mathrm{~d}$ of age (day 0 ), corresponding to an average body weight of $6 \cdot 16$ (SEM 0.26) $\mathrm{kg}$. At day 0 , the piglets underwent surgery for the insertion of a gastrooesophageal flexible polyvinyl tube. Gastro-oesophageal tube feeding was chosen in order to control the level of feed intake. The piglets were briefly anaesthetised prior to surgery by inhalation of halothane for $2-3 \mathrm{~min}$. The surgical procedure was usually completed in less than $10 \mathrm{~min}$. It was performed according to the Certificate of Authorisation to Experiment on Living Animals (certificate number 006708 provided by the French Ministry of Agriculture to J.-P. L.). Then the piglets were placed into individual cages and were allowed free mobility.

The piglets were fasted during the first $48 \mathrm{~h}$ after weaning (day 0 to day 2). Afterwards they were tube-fed six times daily from 06.00 to 21.00 hours. Daily feed intake was adjusted to the pig's metabolic weight according to a prefixed schedule (linear increase from 8.7 to $71.3 \mathrm{gDM} / \mathrm{kg}$ body weight $^{0.75}$ from day 3 to day 11 , then a stable level of $80 \mathrm{~g} \mathrm{DM} / \mathrm{kg}$ body weight ${ }^{0.75}$ from day 12 to day 15$)$. The starvation period mimicked the natural behaviour of the piglets and allowed us to avoid the variability of food level intake observed between piglets in piggeries. Indeed, although some piglets start to eat quickly after weaning, for many of them the first significant feed intake occurs after 2-3 d (Bruininx et al. 2001). The feed intake schedule applied in the present study followed the slow increase of feed intake generally observed until day $8-14$ in breeding conditions (Le Dividich \& Sève, 2000). The level of energy intake at day $15\left(1 \cdot 15 \mathrm{MJ} / \mathrm{kg}\right.$ body weight $\left.{ }^{0.75}\right)$ was on average similar to that of suckling piglets immediately before weaning. Water was offered ad libitum throughout the experiment.

Six piglets per diet and time-point were slaughtered at days $0,2,5,8$ and 15 after weaning. Piglets were killed $3 \mathrm{~h}$ after the last meal except on day 0 when they were killed $1 \mathrm{~h}$ after the last sow's milk meal.

Protocol at slaughtering and sampling. Pigs were weighed, killed by electronarcosis and then immediately exsanguinated. Blood samples were drawn into tubes containing aprotinin and EDTA and immediately centrifuged $(1000 \mathrm{~g}$ for $5 \mathrm{~min}$ ) to obtain plasma. Plasma was stored at $-50^{\circ} \mathrm{C}$ until the gastrin and cholecystokinin (CCK) assays. The gastrointestinal tract was dissected, each digestive segment was weighed full and empty of contents, and the length of the small intestine was measured. The $\mathrm{pH}$ value of the stomach, caecum and proximal colon contents were measured using a $\mathrm{pH}$ meter (704 model; Metrohm Ltd, Herisau, Switzerland) immediately upon collection. Samples of digesta from the proximal jejunum and the proximal colon were collected for bacterial counting. Approximately $1 \mathrm{~g}$ digesta was placed in tubes containing pre-boiled and cooled down Ringer's solution supplemented with $0.3 \mathrm{~g}$ cystein chloride/l and treated for bacterial counting in the following hour. The pancreas was weighed, snap-frozen in liquid nitrogen and stored at $-80^{\circ} \mathrm{C}$ until enzyme activity analysis. Segments $(20 \mathrm{~cm})$ of the proximal jejunum (beginning $20 \mathrm{~cm}$ distal to the ligament of Treitz), the distal ileum (beginning $50 \mathrm{~cm}$ anterior to the ileo-caecal valve) and the proximal colon (beginning $15 \mathrm{~cm}$ distally from the ileo-cecal valve) were removed, immediately placed into Ringer's 
solution and mounted in Ussing chambers (Boudry et al. 2004). From adjacent $20 \mathrm{~cm}$ segments of proximal jejunum and distal ileum, a $1 \mathrm{~cm}$-length piece of tissue was frozen for enzyme mRNA quantification. Mucosal scrapings from the remaining tissue were prepared, weighed before being snap-frozen in liquid nitrogen and then stored at $-80^{\circ} \mathrm{C}$ until enzyme activity analysis. Adjacent pieces of proximal jejunal and distal ileum $(2 \mathrm{~cm}$ each) were fixed in buffered formalin $(10 \%)$ and stored in ethanol-water $(75: 25, \mathrm{v} / \mathrm{v})$ until morphology measurements. All samples were taken at each time-point except the samples for bacterial counts that were collected at days 0,8 and 15 post-weaning due to limitations in microbiology equipment.

\section{Analysis and measurements}

The gastrointestinal tract is a complex organ involved not only in digestion of food components but also in controlling the hydro-mineral absorption-secretion balance, and in the barrier function. Its microflora not only contributes to degrading undigested substrates but actively participates in the resistance to bacterial colonisation and mucosal defence. All these factors interact dynamically and are regulated to provide the necessary nutrients to the organism and to maintain gastrointestinal tract homeostasis and health. Sixty-nine parameters were measured in the present experiment. With these parameters, we got a broad view of the evolution of the structural development of the different organs of the digestive tract and of the digestive, absorptive and epithelial barrier functions of the gut. We also obtained some information on the ecology of the intestinal lumen.

The villi and crypts were isolated from intestinal samples by microdissection and measured according to the technique of Goodlad et al. (1991). Briefly, the specimens were stained with Schiff's reagent after hydrolysis in $1 \mathrm{~mol} / 1 \mathrm{HCl}$ at $60^{\circ} \mathrm{C}$ for $6 \mathrm{~min}$. Bands of villus-crypt units were cut and isolated from the connective tissue, using a fine-gauge syringe needle under a dissecting microscope. The preparation was mounted on a glass slide in a drop of $45 \%$ acetic acid. Villus and crypt length and width were measured using an optical microscope (Eclipse E400; Nikon, Champigny-surMarne, France), a camera (digital camera DMX1200; Nikon) and an image analyser (Lucia software; Laboratory Imaging Ltd, Prague, Czech Republic). Mean values for these parameters were determined for ten individual villi and crypts from each specimen.

The lactase-phlorizin hydrolase $(E C$ 3.2.1.23) and maltase glucoamylase ( $E C$ 3.2.1.20) activities were assayed by the method of Dalqvist (1964) using lactose and maltose as substrates, respectively. The produced glucose was determined using the glucose-6-phosphate dehydrogenase-hexokinase kit (Boehringer, Mannheim, Germany). The specific activities of dipeptidyl-peptidase 4 (EC 3.4.14.5) and amino-peptidase $\mathrm{N}$ (EC 3.4.11.2) were determined by spectrophotometry using glycyl-L-prolyl-4-nitroanilide and glutamic acid $p$-nitroanilide as substrates, respectively (Marion et al. 2005). The absorbance of $p$-nitroaniline released was read at $410 \mathrm{~nm}$ using $p$-nitroaniline as standard. The enzyme activities were expressed as nmol hydrolysed substrates per min (IU) per $\mathrm{mg}$ protein. The protein concentration was measured according to the Lowry method (Lowry et al. 1951).
Analysis of mRNA coding intestinal enzymes was performed on the samples collected in the proximal jejunum. RT-PCR amplification of lactase-phlorizin hydrolase, maltase glucoamylase, amino-peptidase $\mathrm{N}$ and dipeptidyl-peptidase 4 mRNA was carried out as described by Petersen et al. (2001) and Marion et al. (2005). The PCR amplification cycles included denaturation at $95^{\circ} \mathrm{C}$ for $1 \mathrm{~min}$, annealing for $45 \mathrm{~s}$ and extension for $1 \mathrm{~min}$ at $72^{\circ} \mathrm{C}$. An additional extension at $72^{\circ} \mathrm{C}$ for $10 \mathrm{~min}$ was performed, and the samples were then cooled at $4^{\circ} \mathrm{C}$. The annealing temperatures and number of cycles utilised for lactase-phlorizin hydrolase, maltase glucoamylase, amino-peptidase $\mathrm{N}$ and dipeptidyl-peptidase $4 \mathrm{mRNA}$ amplification were $51^{\circ} \mathrm{C}$ and twenty-four cycles, $56^{\circ} \mathrm{C}$ and twenty-seven cycles, $58^{\circ} \mathrm{C}$ and twenty cycles and $59^{\circ} \mathrm{C}$ and twenty cycles, respectively. Ribosomal RNA (18S) was coamplified as internal standard (Quantum RNA $^{\mathrm{TM}} 18 \mathrm{~S}$ Internal Standards; Ambion Ltd, Huntingdon, Cambridgeshire, UK). The amplification products were electrophoresed on a $1 \%$ agarose gel in Tris-borateEDTA buffer and visualised by staining with $0.15 \%$ ethidium bromide. The abundance of enzyme and ribomosal RT-PCR products loaded on gels was quantified using a scanning and imaging system (Phosphorimager Storm 840 and ImageQuant software; Molecular Dynamics, Amersham Biosciences, Piscataway, NJ, USA). For each trial, the PCR products of all the pigs were run on the same gel. Finally, for each sample, the density of enzyme RT-PCR products was expressed relative to the density of the corresponding $18 \mathrm{~S}$ rRNA band.

The secretion function was assessed by basal short-circuit current (Isc) and secretagogue-stimulated Isc (serotonin and theophylline) using Ussing chambers (Boudry et al. 2002, 2004). The glucose absorption was measured by the increase in Isc after addition of glucose. The epithelial barrier function was measured by transmucosal resistance and horseradish peroxidase (HRP) fluxes across the epithelium. The data obtained with the Ussing chamber technique, as well as the villus height, crypt depth, lactase and maltase activities (see Table 2) have been published independently by Boudry et al. (2004). These results were used in the present study as part of the global integrated data analysis.

The specific activities of pancreatic enzymes were assayed in the pancreatic homogenates as previously described (Marion et al. 2003). Briefly, trypsin (EC 3.4.21.4) activity, which is the main pancreatic proteolytic activity after weaning (Pierzynowski et al. 1993), was measured using $N$ - $\alpha$-benzoylL-Arg-p-nitroanilide as substrate according to Laine et al. (1993). The lipase (EC 3.1.1.3) activity was determined by a titrimetric method using tributyrin as substrate. The amylase (EC 3.2.1.1) activity was assayed by spectrophotometry using starch as substrate (Le Huërou et al. 1990). The enzymatic activities were expressed as nmol hydrolysed substrates per min (IU) per mg of protein.

The gastrin was measured in plasma by RIA as previously described by Marion et al. (2003). The rabbit antiserum raised against human gastrin-17, human gastrin-17 standards and $\left[{ }^{125} \mathrm{I}\right]$ gastrin were purchased from Peninsula Laboratories (San Carlos, CA, USA). The CCK concentration was measured on ethanol-extracted plasma using a commercial kit (Euro-diagnostica, Malmö, Sweden). Synthetic CCK 26-30 was used as a standard (Marion et al. 2003).

For bacterial counting, the digestive contents were serially diluted in sterile Ringer's solution supplemented with $0.3 \mathrm{~g}$ 
L-cystein chloride/l. Then $0 \cdot 1 \mathrm{ml}$ of five appropriate dilutions was plated on to various media. The selective media consisted of Rogosa-agar medium (Oxoid, Dardilly, France) and D-coccosel agar (BioMérieux, La Balme les Grottes, France), both supplemented with $0.5 \mathrm{~g}$ L-cystein chloride/l and incubated in anaerobiosis with an AnaerocultA system (Merck, Chelle, France) to promote the growth of the facultative anaerobic lactobacilli and enterococci, respectively. In parallel, MacConkey agar was used to detect coliform bacteria. The non-selective media were based on Columbia agar (Oxoid) with $5 \mathrm{~g}$ glucose/1, $5 \mathrm{~g}$ agar/l and $10 \%$ defibrinated horse blood supplemented with (for total anaerobic bacteria incubated in anaerobiosis) or without (for total aerobic bacteria, incubated in aerobiosis) $0.5 \mathrm{~g}$ L-cystein chloride/l. After $2 \mathrm{~d}$ incubation at $37^{\circ} \mathrm{C}$ the 'aerobic' plates (total aerobic bacteria and coliform bacteria) were examined. The 'anaerobic' plates (total anaerobic bacteria, lactobacilli and enterococci) were counted $3 \mathrm{~d}$ later. The selectivity of the media was checked by Gram staining performed on colonies. The colony-forming units were counted on each plate and for each bacterial type. The values were divided by the mass of digestive contents plated and expressed on a logarithmic basis.

\section{Data analysis}

A total of sixty-nine variables grouped in eight families were analysed (Table 2): the gut and digesta characteristics, the intestinal morphometry, the intestinal and pancreatic enzymes, the intestinal secretory and absorptive capacities, the intestinal barrier function, the plasma concentration of digestive hormones, and the microflora in digesta. For each variable, variance homogeneity of data was assessed using the Hartley test (Hartley, 1950).

The data for each variable were then subjected to ANOVA using the General Linear Model procedure of Statistical Analysis Systems statistical software package version 6 (SAS Institute, Cary, NC, USA) to test the effect of diet, time, pair of piglets, replication, diet $\times$ replication and diet $\times$ time interactions at days 5, 8 and 15 using the Snedecor $F$ test. As the effects of diet and diet $\times$ time interaction were not significant for most of the variables, the diet factor was removed from the model and a second analysis was performed with the data from days $0,2,5,8$ and 15. For both analyses, when the probability of the time effect was lower than 0.05 , the differences between the means were further analysed using the Student's $t$ test. The values are presented as least-squares means and their pooled standard errors. Differences are declared significant at an $\alpha$ level of $P<0.05$.

In order to have an overview of the weaning-induced changes on gut morphology, physiology and ecology, PCA were performed on the set of data using the Copri and Defac procedures of Spad statistical software version 5.5 (Decisia, Pantin, France). The data were standardised before PCA, i.e. for each variable the data were corrected by the mean and divided by the standard deviation of this variable. PCA allows a reduction in the number of variables by creating successive linear combinations of the variables, so-called 'principal components' or 'factors'. Factor loadings were calculated for each variable and each piglet. Factor loadings can be interpreted as correlation coefficients between variables and factors (Lebart et al. 1995). The variances extracted by the factors are called the eigenvalues. To identify the number of factors to be retained, we used the rule of the eigenvalue $>1$ in a first step. This criterion is the most widely used and is based on the rationale that each factor retained should explain more variance than a single original variable in the data set. In a second step, a plot of the eigenvalues (named 'scree' test) was established. The factors to be retained appeared to be before a clear break corresponding to eigenvalue $>1 \cdot 25$. PCA also allows the identification of relationships among multiple variables. The correlations between variables, as well as the correlations between variables and factors, were tested by the Student's $t$ test. A test-value specific for the Spad software was given (Morineau, 1984). A test value $\geq 2$ corresponded to $P \leq 0 \cdot 05$.

Three PCA were carried out according to days of observation and variables. The first analysis (PCA 1) dealt with variables measured in pigs slaughtered at days 0,2 and 5 post-weaning (acute phase, see later). The second analysis (PCA 2) was performed with data from days 5, 8 and 15 (adaptative phase, see later). These PCA were first carried out with fifty-nine variables (excluding variables of bacterial counts), measured in thirty-two and thirty-six piglets, for PCA 1 and PCA 2, respectively. For PCA 1, because one piglet alone explained more than $25 \%$ of the second factor, it was excluded from the analysis. Then we excluded from the final analyses the variables that did not load on any factor retained (correlation coefficient between variables and factor $r \leq 0.5)$. Moreover, when several variables were highly significantly correlated together $(r>0.55, P<0.05)$ inside a family of variables, only the main representative variable, i.e. with the highest factors loading, was kept for analysis (see later). A third PCA (PCA 3) was conducted with the representative variables retained in the final analysis of data from days 5, 8 and 15 (PCA 2), in addition to the ten variables characterising gut microbiology and $\mathrm{pH}$ values of colonic and caecal contents that are influenced directly by bacterial fermentation. This third PCA was also optimised as described earlier.

\section{Results}

Four piglets, two from day 0 and two from day 2, were excluded from analysis because of a high number of missing values for these piglets. Consequently, data resulted from fifty-six piglets only.

\section{Influence of diet composition on gut physiology and microbiology}

The dietary treatment did not affect growth or the frequency of diarrhoea. In addition, the changes in the architecture and function of the gut of piglets did not depend on the diet. The only variable significantly affected by the diet was the $\mathrm{pH}$ of the digestive contents, which was significantly lowered in the caecum of pigs fed with the wheat-based diet $(P=0 \cdot 02)$. Therefore, the data from the two dietary treatments were pooled for subsequent analysis. 
Table 2. Body weight, organ and digesta characteristics, intestinal physiology and microbiology in relation to day post-weaning*

\begin{tabular}{|c|c|c|c|c|c|c|c|c|}
\hline \multirow[b]{2}{*}{ Variable } & \multirow[b]{2}{*}{ Site } & \multicolumn{5}{|c|}{ Day post-weaning } & \multirow[b]{2}{*}{ SEM } & \multirow[b]{2}{*}{ Significance } \\
\hline & & 0 & 2 & 5 & 8 & 15 & & \\
\hline BW at slaughter $(\mathrm{kg})$ & & $6 \cdot 4^{\mathrm{b}}$ & $6 \cdot 0^{\mathrm{b}}$ & $6 \cdot 2^{\mathrm{b}}$ & $6 \cdot 7^{\mathrm{b}}$ & $8 \cdot 4^{\mathrm{a}}$ & 0.3 & $<0.0001$ \\
\hline \multicolumn{9}{|l|}{ Organ and digesta characteristics } \\
\hline \multirow{4}{*}{ Organ weight (g/kg BW) } & Pancreas & $1 \cdot 2^{\mathrm{c}}$ & $1 \cdot 2^{\mathrm{c}}$ & $1 \cdot 2^{\mathrm{c}}$ & $1.4^{\mathrm{b}}$ & $1.8^{\mathrm{a}}$ & 0.1 & $<0.0001$ \\
\hline & Stomach & $5 \cdot 0^{\mathrm{C}}$ & $5 \cdot 1^{\mathrm{c}}$ & $5 \cdot 6^{\mathrm{b}}$ & $5 \cdot 7^{\mathrm{b}}$ & $6 \cdot 5^{\mathrm{a}}$ & 0.2 & $<0.0001$ \\
\hline & Small intestine & $28 \cdot 2^{b c}$ & $23.0^{\mathrm{d}}$ & $28 \cdot 0^{\mathrm{C}}$ & $32 \cdot 2^{\mathrm{b}}$ & $41.9^{\mathrm{a}}$ & 1.5 & $<0.0001$ \\
\hline & Large intestine & $8 \cdot 3^{\mathrm{bc}}$ & $7 \cdot 2^{\mathrm{C}}$ & $9 \cdot 3^{\mathrm{bc}}$ & $10 \cdot 6^{b}$ & $13 \cdot 8^{\mathrm{a}}$ & 1.0 & 0.0003 \\
\hline $\begin{array}{l}\text { Length of the small intestine } \\
(\mathrm{m} / \mathrm{kg} \mathrm{BW})\end{array}$ & & 1.3 & $1 \cdot 3$ & 1.4 & $1 \cdot 3$ & $1 \cdot 3$ & 0.1 & 0.746 \\
\hline \multirow[t]{3}{*}{ Digesta content (g/kg BW) } & Stomach & $7 \cdot 3^{\mathrm{c}}$ & $2 \cdot 7^{\mathrm{c}}$ & $8 \cdot 7^{\mathrm{C}}$ & $19 \cdot 4^{\mathrm{b}}$ & $27 \cdot 7^{\mathrm{a}}$ & 3.0 & $<0.0001$ \\
\hline & Small intestine & $4 \cdot 9^{\mathrm{c}}$ & $4 \cdot 0^{\mathrm{c}}$ & $14 \cdot 1^{\mathrm{b}}$ & $16 \cdot 9^{\mathrm{ab}}$ & $21 \cdot 8^{\mathrm{a}}$ & $2 \cdot 0$ & $<0.0001$ \\
\hline & Large intestine & $8 \cdot 2^{c}$ & $6 \cdot 9^{c}$ & $21 \cdot 1^{b}$ & $22 \cdot 7^{\mathrm{b}}$ & $32 \cdot 7^{\mathrm{a}}$ & 1.8 & $<0.0001$ \\
\hline \multirow[t]{3}{*}{$\mathrm{pH}$ of digesta } & Stomach & $3.2^{\mathrm{a}}$ & $2 \cdot 3^{\mathrm{b}}$ & $2 \cdot 4^{\mathrm{b}}$ & $3 \cdot 1^{\mathrm{a}}$ & $3 \cdot 0^{\mathrm{a}}$ & 0.2 & 0.001 \\
\hline & Caecum & $6 \cdot 4^{\mathrm{b}}$ & $6 \cdot 9^{\mathrm{a}}$ & $5 \cdot 9^{\mathrm{c}}$ & $5.9^{\mathrm{c}}$ & $5 \cdot 8^{\mathrm{C}}$ & 0.1 & $<0.0001$ \\
\hline & Colon & $6 \cdot 6^{\mathrm{a}}$ & $6 \cdot 6^{\mathrm{a}}$ & $6 \cdot 3^{\mathrm{ab}}$ & $6 \cdot 4^{\mathrm{a}}$ & $6 \cdot 0^{\mathrm{b}}$ & 0.2 & 0.029 \\
\hline \multicolumn{9}{|l|}{ Mass of the small intestine $(\mathrm{g} / \mathrm{cm})$} \\
\hline Entire & Proximal jejunum & $0.28^{\mathrm{b}}$ & $0.21^{\mathrm{c}}$ & $0.28^{\mathrm{b}}$ & $0.33^{\mathrm{b}}$ & $0.46^{a}$ & 0.02 & $<0.0001$ \\
\hline & Distal ileum & $0.42^{\mathrm{b}}$ & $0.37^{\mathrm{b}}$ & $0.39^{\mathrm{b}}$ & $0.44^{\mathrm{b}}$ & $0.54^{\mathrm{a}}$ & 0.03 & $<0.0001$ \\
\hline Mucosa & Proximal jejunum & $0 \cdot 17^{\mathrm{b}}$ & $0.11^{c}$ & $0 \cdot 17^{\mathrm{b}}$ & $0 \cdot 19^{\mathrm{b}}$ & $0.29^{a}$ & 0.01 & $<0.0001$ \\
\hline & Distal ileum & $0.27^{\mathrm{ab}}$ & $0.22^{\mathrm{c}}$ & $0.23^{\mathrm{C}}$ & $0.25^{\mathrm{bc}}$ & $0.31^{a}$ & 0.02 & 0.0015 \\
\hline Muscularis & Proximal jejunum & $0 \cdot 11^{\mathrm{bc}}$ & $0.09^{c}$ & $0.11^{\mathrm{bc}}$ & $0.14^{\mathrm{b}}$ & $0.17^{\mathrm{a}}$ & 0.01 & $<0.0001$ \\
\hline & Distal ileum & $0 \cdot 15^{\mathrm{bc}}$ & $0 \cdot 15^{\mathrm{c}}$ & $0 \cdot 16^{\mathrm{bc}}$ & $0.19^{b}$ & $0.23^{a}$ & 0.01 & $<0.0001$ \\
\hline Plasma concentration of digestive ho & nones (pmol/l) & & & & & & & \\
\hline Cholecystokinin & & $6 \cdot 4^{\mathrm{b}}$ & $0.3^{\mathrm{c}}$ & $3.1^{\mathrm{bc}}$ & $8 \cdot 4^{\mathrm{b}}$ & $14.8^{\mathrm{a}}$ & $2 \cdot 1$ & 0.0003 \\
\hline Gastrin & & $13 \cdot 1^{\mathrm{a}}$ & $2 \cdot 5^{\mathrm{bc}}$ & $2 \cdot 4^{\mathrm{c}}$ & $5 \cdot 7^{\mathrm{bc}}$ & $8.5^{\mathrm{ab}}$ & $2 \cdot 2$ & 0.007 \\
\hline Specific activity of pancreatic enzyme & (IU/mg protein $\dagger)$ & & & & & & & \\
\hline Lipase & Pancreas & $18^{\mathrm{a}}$ & $24^{\mathrm{a}}$ & $11^{\mathrm{b}}$ & $7^{\mathrm{b}}$ & $7^{\mathrm{b}}$ & 2 & $<0.0001$ \\
\hline Trypsin & Pancreas & $86^{\mathrm{bc}}$ & $108^{\mathrm{b}}$ & $56^{d}$ & $80^{\mathrm{cd}}$ & $140^{\mathrm{a}}$ & 10 & $<0.0001$ \\
\hline Amylase & Pancreas & $35^{\mathrm{a}}$ & $32^{a b}$ & $20^{\mathrm{b}}$ & $33^{\mathrm{ab}}$ & $43^{\mathrm{a}}$ & 5 & 0.021 \\
\hline Intestinal morphometry $(\mu \mathrm{m})$ & & & & & & & & \\
\hline Villus length & Proximal jejunum & $597^{a}$ & $356^{c}$ & $359^{c}$ & $377^{\mathrm{c}}$ & $457^{\mathrm{b}}$ & 27 & $<0.0001$ \\
\hline & Distal ileum & 340 & 295 & 268 & 329 & 317 & 20 & 0.128 \\
\hline Villus width & Proximal jejunum & $151^{\mathrm{b}}$ & $143^{\mathrm{b}}$ & $150^{\mathrm{b}}$ & $161^{\mathrm{a}}$ & $184^{\mathrm{a}}$ & 7 & 0.0008 \\
\hline & Distal ileum & $113^{\mathrm{c}}$ & $104^{\mathrm{c}}$ & $119^{\mathrm{bc}}$ & $132^{\mathrm{b}}$ & $149^{\mathrm{a}}$ & 5 & $<0.0001$ \\
\hline Crypt depth & Proximal jejunum & $216^{c}$ & $211^{\mathrm{c}}$ & $367^{\mathrm{a}}$ & $304^{b}$ & $308^{\mathrm{b}}$ & 13 & $<0.0001$ \\
\hline & Distal ileum & $156^{\mathrm{c}}$ & $146^{\mathrm{c}}$ & $194^{\mathrm{b}}$ & $204^{\mathrm{b}}$ & $240^{\mathrm{a}}$ & 10 & $<0.0001$ \\
\hline Crypt width & Proximal jejunum & $31^{\mathrm{b}}$ & $29^{b}$ & $31^{\mathrm{b}}$ & $31^{\mathrm{b}}$ & $34^{\mathrm{a}}$ & 1 & 0.012 \\
\hline & Distal ileum & $29^{\mathrm{ab}}$ & $27^{\mathrm{b}}$ & $29^{\mathrm{ab}}$ & $31^{\mathrm{a}}$ & $31^{\mathrm{a}}$ & 1 & 0.037 \\
\hline Intestinal enzyme activities and gene & xpression & & & & & & & \\
\hline Specific activity of small intestinal & Izymes (IU/mg prote & & & & & & & \\
\hline Lactase & Proximal jejunum & $59^{a}$ & $48^{\mathrm{a}}$ & $17^{\mathrm{b}}$ & $17^{\mathrm{b}}$ & $12^{\mathrm{b}}$ & 5 & $<0.0001$ \\
\hline & Distal ileum & $11 \cdot 4^{\mathrm{a}}$ & $3.9^{\mathrm{b}}$ & $1 \cdot 7^{\mathrm{b}}$ & $3.3^{\mathrm{b}}$ & $1 \cdot 4^{\mathrm{b}}$ & 1.5 & $<0.0001$ \\
\hline Maltase & Proximal jejunum & 42 & 37 & 31 & 43 & 43 & 5 & 0.399 \\
\hline & Distal ileum & 29 & 27 & 33 & 48 & 45 & 7 & 0.1053 \\
\hline Amino-peptidase $\mathrm{N}$ & Proximal jejunum & $51^{a}$ & $26^{\mathrm{b}}$ & $28^{\mathrm{b}}$ & $31^{\mathrm{b}}$ & $31^{b}$ & 4 & 0.001 \\
\hline & Distal ileum & $48^{a}$ & $21^{\mathrm{b}}$ & $24^{\mathrm{b}}$ & $31^{\mathrm{b}}$ & $27^{\mathrm{b}}$ & 5 & 0.0023 \\
\hline Dipeptidyl-peptidase 4 & Proximal jejunum & $19^{a}$ & $7^{\mathrm{b}}$ & $6^{\mathrm{b}}$ & $7^{\mathrm{b}}$ & $7^{\mathrm{b}}$ & 3 & 0.0657 \\
\hline & Distal ileum & $30^{\mathrm{a}}$ & $14^{\mathrm{b}}$ & $9^{b}$ & $12^{\mathrm{b}}$ & $10^{\mathrm{b}}$ & 4 & 0.0009 \\
\hline Enzyme mRNA level (density ratio, & AUł) & & & & & & & \\
\hline Lactase & Proximal jejunum & 1.25 & 0.95 & 0.83 & 0.73 & 0.82 & 0.16 & 0.187 \\
\hline Maltase & Proximal jejunum & $0.28^{\mathrm{b}}$ & $0.44^{b}$ & $1 \cdot 32^{\mathrm{a}}$ & $1 \cdot 26^{a}$ & $1.43^{\mathrm{a}}$ & $0 \cdot 18$ & $<0.0001$ \\
\hline Amino-peptidase $\mathrm{N}$ & Proximal jejunum & 1.46 & 1.36 & 1.28 & 1.37 & 1.26 & 0.11 & 0.770 \\
\hline Dipeptidyl-peptidase 4 & Proximal jejunum & 0.50 & 0.41 & 0.45 & 0.45 & 0.34 & 0.05 & 0.335 \\
\hline Intestinal secretory and absorptive ce & acities $\left(\mu \mathrm{A} / \mathrm{cm}^{2}\right)$ & & & & & & & \\
\hline Basal short-circuit current & Proximal jejunum & $110^{\mathrm{bc}}$ & $209^{a}$ & $170^{\mathrm{ab}}$ & $94^{\mathrm{C}}$ & $56^{c}$ & 25 & 0.039 \\
\hline & Distal ileum & 25 & 11 & 5 & -40 & -29 & 23 & 0.296 \\
\hline & Colon & 73 & 101 & 55 & 73 & 72 & 8 & $0 \cdot 181$ \\
\hline Theophylline-induced secretion & Proximal jejunum & 326 & 312 & 366 & 185 & 125 & 57 & 0.054 \\
\hline & Distal ileum & 192 & 388 & 200 & 302 & 175 & 68 & 0.295 \\
\hline & Colon & 214 & 124 & 220 & 176 & 170 & 25 & 0.173 \\
\hline Serotonin-induced secretion & Proximal jejunum & 194 & 306 & 179 & 200 & 76 & 30 & 0.149 \\
\hline & Distal ileum & 223 & 294 & 179 & 355 & 169 & 80 & 0.625 \\
\hline & Colon & 43 & 75 & 48 & 53 & 33 & 11 & 0.203 \\
\hline Glucose absorption & Proximal jejunum & $530^{\mathrm{b}}$ & $945^{a}$ & $372^{\mathrm{bc}}$ & $300^{\mathrm{bc}}$ & $88^{\mathrm{C}}$ & 122 & 0.007 \\
\hline & Distal ileum & 779 & 367 & 296 & 194 & 680 & 81 & 0.068 \\
\hline Intestinal barrier function & & & & & & & & \\
\hline Transmucosal resistance $\left(\Omega \mathrm{cm}^{2}\right)$ & Proximal jejunum & 28 & 9 & 34 & 26 & 29 & 4 & 0.111 \\
\hline & Distal ileum & $15^{\mathrm{b}}$ & $12^{\mathrm{b}}$ & $32^{\mathrm{a}}$ & $25^{\mathrm{ab}}$ & $29^{a}$ & 4 & 0.007 \\
\hline & Colon & 44 & 57 & 47 & 42 & 40 & 6 & 0.262 \\
\hline
\end{tabular}


Table 2. Continued

\begin{tabular}{|c|c|c|c|c|c|c|c|c|}
\hline \multirow[b]{2}{*}{ Variable } & \multirow[b]{2}{*}{ Site } & \multicolumn{5}{|c|}{ Day post-weaning } & \multirow[b]{2}{*}{ SEM } & \multirow[b]{2}{*}{ Significance } \\
\hline & & 0 & 2 & 5 & 8 & 15 & & \\
\hline \multirow[t]{3}{*}{ HRP fluxes $\left(\mathrm{ng} / \mathrm{cm}^{2}\right.$ per $\left.\mathrm{h}\right)$} & Proximal jejunum & $997^{\mathrm{a}}$ & $229^{c}$ & $360^{\mathrm{bc}}$ & $672^{\mathrm{ab}}$ & $344^{\mathrm{bc}}$ & 110 & 0.013 \\
\hline & Distal ileum & 367 & 441 & 163 & 195 & 419 & 84 & 0.198 \\
\hline & Colon & 754 & 389 & 629 & 324 & 1020 & 200 & 0.416 \\
\hline \multicolumn{9}{|c|}{ Microflora in digesta (log cfu/g digesta) } \\
\hline \multirow[t]{2}{*}{ Total anaerobic bacteria } & Proximal jejunum & $7 \cdot 0$ & ND & ND & 6.9 & 6.0 & 0.4 & 0.119 \\
\hline & Colon & $9 \cdot 5^{\mathrm{b}}$ & ND & ND & $9 \cdot 8^{\mathrm{a}}$ & $9 \cdot 6^{\mathrm{b}}$ & 0.1 & 0.009 \\
\hline \multirow[t]{2}{*}{ Total aerobic bacteria } & Proximal jejunum & $6 \cdot 3^{\mathrm{ab}}$ & ND & ND & $6 \cdot 6^{\mathrm{a}}$ & $5 \cdot 4^{\mathrm{b}}$ & 0.3 & 0.042 \\
\hline & Colon & $8.5^{\mathrm{b}}$ & ND & ND & $9 \cdot 3^{a}$ & $8 \cdot 4^{\mathrm{b}}$ & 0.2 & 0.015 \\
\hline \multirow[t]{2}{*}{ Lactobacilli } & Proximal jejunum & $6 \cdot 8$ & ND & ND & 6.5 & $5 \cdot 8$ & 0.4 & 0.225 \\
\hline & Colon & $8 \cdot 8^{\mathrm{b}}$ & ND & ND & $9 \cdot 5^{a}$ & $9 \cdot 2^{b}$ & 0.2 & 0.011 \\
\hline \multirow[t]{2}{*}{ Enterobacteria } & Proximal jejunum & 4.3 & ND & ND & 5.0 & $4 \cdot 2$ & 0.4 & 0.243 \\
\hline & Colon & $7 \cdot 5^{\mathrm{b}}$ & ND & ND & $8 \cdot 3^{a}$ & $7.0^{\mathrm{b}}$ & 0.2 & 0.004 \\
\hline \multirow[t]{2}{*}{ Enterococci } & Proximal jejunum & $6 \cdot 4$ & ND & ND & $6 \cdot 1$ & $5 \cdot 0$ & 0.4 & 0.087 \\
\hline & Colon & $8 \cdot 4^{\mathrm{b}}$ & ND & ND & $9 \cdot 2^{a}$ & $8 \cdot 6^{\mathrm{b}}$ & 0.2 & 0.004 \\
\hline
\end{tabular}

AU, arbitrary units; BW, body weight; cfu, colony-forming units; HRP, horseradish peroxidase; ND, not determined.

$\mathrm{a}, \mathrm{b}, \mathrm{c}, \mathrm{d}$ Mean values within a row with unlike superscript letters were significantly different $(P<0.05)$.

${ }^{*}$ For details of procedures, see pp. 46-48.

†Enzyme activities are expressed as nmol hydrolysed substrate/min per mg homogenate protein.

¥The density of enzyme RT-PCR products was expressed relative to the density of the corresponding $18 \mathrm{~S}$ rRNA band.

\section{Influence of the time post-weaning on gut physiology and microbiology}

Dramatic changes in the gut structure, functions and microbiology were observed following weaning (Table 2). The relative weight of the small intestine decreased by $18 \%$ $(P<0.0001)$ between day 0 and day 2 , whereas that of other segments was not affected by the fasting period. The total weight of the gut reached a value $50 \%$ higher at day 15 than at day 0 (not shown). The increase in the intestinal mass resulted from the increase of the mass of both mucosa and muscularis layer masses in the proximal part of the small intestine $(P<0.0001)$. The post-weaning increase of the tissue mass was less important in the ileum than in the proximal jejunum and it was also delayed, starting on day 8 compared to day 5 in the jejunum. The relative weight of the pancreas did not vary between day 0 and day 5 while it increased thereafter $(P<0 \cdot 001)$.

The gastrin and CCK levels in plasma strongly decreased during the fasting period $(P<0 \cdot 01)$ and increased progressively thereafter $(P<0 \cdot 001)$. The activity of lipase and trypsin in the pancreas increased by 33 and $25 \%$, respectively, between days 0 and 2. From day 2 to day 5 , all the pancreatic parameters decreased sharply. Afterwards, the trypsin and amylase activities were stimulated whereas that of lipase decreased.

In the proximal jejunum, the villus height decreased by $40 \%$ from days 0 to 2 . It increased thereafter but was still $77 \%$ lower at day 15 when compared with the value measured at day 0 . By contrast, in the ileum, the villi were not significantly affected. At this site, the crypts deepened from day 2, reaching values $64 \%$ higher at day 15 than at day 2 . The lactase specific activity decreased by nearly $90 \%$ between days 0 and 5 at both intestinal sites and remained low until day 15 . The maltase activity was not affected by the post-weaning fast in the jejunum but it tended to increase in the ileum between day 2 and $15(+66 \%, P=0 \cdot 10)$. The specific activities of amino-peptidase $\mathrm{N}$ and dipeptidyl-peptidase 4 were halved at both sites during the fasting period, stayed at low levels afterwards in the proximal jejunum and tended to increase in the ileum ( $+48 \%$ from days 2 to 8 for amino-peptidase $\mathrm{N}, P=0 \cdot 12$ ). The maltase mRNA levels increased progressively from days 0 to day 5 whereas the lactase, amino-peptidase $\mathrm{N}$ and dipeptidyl-peptidase 4 mRNA levels were not changed during the whole post-weaning period.

The data obtained by the Ussing chamber were published by Boudry et al. (2004). Briefly, the basal Isc increased by $90 \%$ from day 0 to 2 in the jejunum. At the same time, an increase in the glucose absorption $(+78 \%)$ and a drop of the mucosal resistance $(-68 \%)$ were observed. These parameters returned to pre-weaning values at day 5 . In the jejunum, the responses to secretagogue (theophylline and serotonin) and the glucose absorption were $60 \%$ lower at day 15 than at day 0 . The ileal transmucosal resistance increased on day 5 and was stable thereafter. The HRP fluxes in the jejunum declined on day 2 and stayed at this low level until day 15 , except at day 8 .

The level of total aerobic bacteria in the jejunal contents was similar on day 0 and 8 but it decreased between days 8 and $15(P<0 \cdot 04)$. The same trend was observed for enterococci $(P=0.09)$. In the colon contents, the total anaerobes, aerobes, lactobacilli, enterobacteria and enterococci levels were higher on day 8 than on day 0 , and decreased thereafter.

\section{Global statistical analysis}

PCA 1. PCA of data from days 0 to 5 (acute phase) was optimised by removing from the analysis the variables that did not load on any factor retained. It concerned: the weight of the large intestine, the $\mathrm{pH}$ of digestive contents from the stomach and the colon, the width of jejunal villi and crypts and ileal crypts, the length of ileal villi, the maltase activity in the jejunal and the ileal mucosa, the level of mRNA coding for enzymes in the mucosa, the glucose absorption and 5-hydroxytryptamine (5HT)-induced secretion of the jejunal mucosa, the HRP fluxes and the basal Isc of ileal and colonic mucosa, the basal resistance, the 5-hydroxytryptamineinduced and theophylline-induced secretions of colonic 
mucosa, the pancreatic lipase and amylase activities as well as the gastrin level in plasma. Redundant variables were also removed as described earlier. As an example, the decrease of the specific activities of lactase, dipeptidyl-peptidase 4 and amino-peptidase $\mathrm{N}$ observed between days 0 and 5 were highly correlated within an intestinal site $(r>0.66$ and $r>0.70$ for jejunal and ileal activities, respectively), and only the activity of lactase was used in the optimised analysis. Similarly, significant correlations were observed between: the weight of digestive contents in the small and the large intestine $(r$ 0.79); the weight of the stomach and pancreas ( $r$ 0.61); the mass of the proximal jejunum and that of mucosa and muscularis ( $r$ 0.88, 0.88, and 0.55 between mucosa and muscularis); the mass of ileal mucosa and muscularis and the mass of ileum ( $r 0.69$ and 0.69); the crypt depth and villus width in ileum ( $r 0.66)$ and between the theophylline and 5-hydroxytryptamine-induced secretion in ileum ( $r$ 0.70). The final analysis comprised thirty-one piglets and twenty-three variables listed in Table 3. Five major factors accounting for $71 \%$ of the variance among piglets were retained according to the eigenvalue $>1.25$ criterion (Table 3). Factor 1 explained $26 \%$ of total variance, and significantly discriminated piglets slaughtered at day 2 from day 5. The variables with the highest loading with factor 1 (indicating strong associations between the variables and the factor) were: the amount of gastric and small intestinal digestive contents $(r-0.68$ and -0.76 , respectively); the small intestine weight $(r-0 \cdot 68)$; the jejunal mucosa mass and crypt depth ( $r-0.63$ and -0.70 , respectively); the $\mathrm{pH}$ of caecal digesta $(r 0.57)$ and the trypsin activity $(r 0.56)$. The variables measuring the structural and functional characteristics of the ileal mucosa were also closely linked with the factor 1 ( $r-0.65,-0.72$ and 0.53 for crypt depth, basal resistance and theophylline-induced secretion, respectively). Factor 2 explained $16 \%$ of the total variance and was representative of piglets at day 0 . It was associated with the jejunal villus height ( $r$ 0.90), HRP flux ( $r$ 0.71) and lactase activity in the proximal jejunal mucosa $(r 0.58)$, with the plasma CCK concentration $(r 0.70)$ and also with the tissue mass $(r 0.51)$ and lactase activity ( $r$ 0.59) of distal ileal mucosa. Factors 3, 4 and 5 explained 12,10 and $7 \%$ of the total variance, respectively, but they did not discriminate any groups of piglets.

$P C A$ 2. The PCA of data from day 5 to day 15 (adaptative phase) was optimised by removing from the analysis the variables that did not load on any factor retained. It concerned: the weight of stomach, the small intestine length and the digestive content, the weight of the large intestine, the $\mathrm{pH}$ of digestive contents from stomach, caecum and colon, the length and width of the jejunal crypts and ileal villi, the width of the ileal crypts, the maltase in the jejunal mucosa, the lactase

Table 3. Description of the major factors obtained by principal component analysis (PCA) of twenty-three variables characterising gut physiology during the acute phase post-weaning (thirty-one piglets slaughtered on the day of weaning and days 2 and 5 after weaning)

\begin{tabular}{|c|c|c|c|c|c|}
\hline Factor† & 1 & 2 & 3 & 4 & 5 \\
\hline$\%$ Variability explained & 26 & 16 & 12 & 10 & 7 \\
\hline$\%$ Cumulated & 26 & 42 & 54 & 64 & 71 \\
\hline \multicolumn{6}{|l|}{ Coordinates of the modality } \\
\hline \multicolumn{6}{|l|}{ Time } \\
\hline Day 0 & 0.41 & $2 \cdot 73^{*}$ & 0.27 & -0.18 & 0.20 \\
\hline Day 2 & $2 \cdot 32^{*}$ & -1.09 & 0.09 & 0.58 & -0.55 \\
\hline Day 5 & $-2 \cdot 24^{*}$ & $-1 \cdot 14$ & -0.28 & -0.35 & 0.31 \\
\hline \multicolumn{6}{|l|}{ Factor loading of variables $\ddagger$} \\
\hline Small intestine digestive content & -0.76 & -0.35 & & & \\
\hline Basal resistance of distal ileum & -0.72 & & & -0.35 & \\
\hline Crypt depth in proximal jejunum & -0.70 & & -0.37 & & \\
\hline Digestive content in stomach & -0.68 & & & & 0.52 \\
\hline Weight of the small intestine & -0.68 & 0.40 & & 0.40 & \\
\hline Crypt depth in ileum & -0.65 & & & & \\
\hline Mass of proximal jejunum & -0.63 & 0.38 & & & \\
\hline $\mathrm{pH}$ of caecal digesta & 0.57 & & & & \\
\hline Trypsin activity & 0.56 & & & 0.42 & -0.37 \\
\hline Theophylline-induced secretion in distal ileum & 0.53 & & & & 0.37 \\
\hline Glucose absorption in distal ileum & 0.50 & & & & 0.45 \\
\hline Villus length in proximal jejunum & & 0.90 & & & \\
\hline HRP fluxes across proximal jejunum & & 0.71 & -0.43 & & \\
\hline Cholecystokinin plasma concentration & -0.49 & 0.70 & & & \\
\hline Lactase activity in ileum & & 0.59 & 0.45 & 0.38 & \\
\hline Lactase activity in proximal jejunum & 0.54 & 0.58 & & & \\
\hline Mass of ileal mucosa & & 0.51 & -0.48 & & \\
\hline Theophylline-induced secretion in proximal jejunum & & & -0.73 & & \\
\hline Length of the small intestine & & & 0.70 & 0.39 & \\
\hline Basal short-circuit current of proximal jejunum & & -0.42 & -0.46 & 0.46 & \\
\hline Weight of stomach & -0.48 & & & 0.73 & \\
\hline Basal resistance of proximal jejunum & -0.42 & & 0.43 & -0.61 & \\
\hline Density of ileal muscularis & -0.43 & & 0.45 & & -0.60 \\
\hline
\end{tabular}

HRP, horseradish peroxidase.

${ }^{*}$ Indicates that modality was significantly represented by the respective factor $(P<0.05)$.

† Factors or principal components created by PCA are linear combinations of the original variables.

$\ddagger$ Only correlations with $r \geq 0.35$ are indicated. 
and amino-peptidase $\mathrm{N}$ activities in the jejunal and ileal mucosa, the level of mRNA coding for lactase, the glucose absorption and HRP fluxes across the jejunum, the Isc basal and HRP fluxes for the ileum, all parameters measuring absorption, secretion and barrier capacity of the colonic mucosa and plasma gastrin concentration. Then redundant variables were removed. The variables retained are listed in Table 4. The correlations between variables measured within a digestive site are reported in Fig. 1. The pancreas weight, that was significantly $(P<0 \cdot 05)$ correlated to the small intestine weight and the colonic digestive contents $(r \geq 0.61)$, was selected as representative of that group of variables. The mass of the proximal jejunum segment was correlated with the mass of the jejunal mucosa and muscularis at the same site ( $r 0.95$ and 0.86$)$ and with the mass of the distal ileum, of the mucosa and of the muscularis ( $r$ 0.55-0.89). Correlations between the jejunal specific activity of aminopeptidase $\mathrm{N}$ and that of dipeptidyl-peptidase 4 ( $r$ 0.78), between the ileal specific activity of maltase and that of dipeptidyl-peptidase 4 ( $r 0.69$ ), and between the specific activity of pancreatic trypsin and that of amylase $(r 0.67)$ were significant $(P<0 \cdot 05)$. We selected the jejunal amino-peptidase $\mathrm{N}$, the ileal maltase and pancreatic trypsin activities as representative variables. In the ileum, the glucose absorption, and the 5hydroxytryptamine- and theophylline-induced secretions were correlated together $(r \geq 0 \cdot 76)$. The glucose absorption was the variable kept as a representive of that group of variables. The final analysis concerned thirty-six piglets and seventeen variables (Table 4). PCA 2 resulted in five major factors accounting for $69 \%$ of the variance among the piglets.
Factor 1 explained $26 \%$ of the variability and significantly discriminated piglets slaughtered at day 5 from day 15 . The variables with the highest loading with factor 1 were mainly those measuring phenomena occurring in the proximal small intestine. Factor 2 explained $15 \%$ of the total variance. It did not discriminate any age-group of piglets. It was associated with variables measuring phenomena occurring mainly in the distal ileal mucosa. Factors 3, 4 and 5 explained 10, 8.9 and $8.2 \%$ of the total variance, respectively, and did not discriminate any group of piglets.

$P C A$ 3. The PCA with microbiological data (days 8 and 15) was optimised by removing variables that did not load with the main factors (i.e. weight of stomach content, specific activity of amino-peptidase $\mathrm{N}$ in the proximal jejunum, dipeptidyl-peptidase 4 mRNA, basal resistance, 5-hydroxytryptamine-induced and theophylline-induced secretions of the jejunal mucosa, plasma CCK level and anaerobic bacteria counts in the colonic digesta). Moreover, all bacteria counts in the proximal jejunum were correlated together $(r$ 0.54$0 \cdot 97, P<0.05)$. Therefore, the total aerobic count was used as a representative for all other bacterial species at this gut site. In the colonic digestive contents only the level of enterobacteria and total aerobic bacteria were significantly $(P<0.05)$ correlated $(r 0.57)$, and total aerobic bacteria were suppressed from the analysis. Finally, the optimised PCA of data from days 8 and 15 with microbiology variables concerned twenty-four piglets and seventeen variables (Table 5). The PCA 3 resulted in four major factors accounting for $68 \%$ of the variance among piglets. Factor 1 explained $26 \%$ of the variability and significantly discriminated piglets

Table 4. Description of the major factors obtained by principal component analysis (PCA) of seventeen variables characterising gut physiology during the adaptative phase post-weaning (thirty-six piglets slaughtered on days 5,8 and 15 after weaning)

\begin{tabular}{|c|c|c|c|c|c|}
\hline Factors $†$ & 1 & 2 & 3 & 4 & 5 \\
\hline$\%$ Variability explained & 26 & 15 & 10 & 8.9 & $8 \cdot 2$ \\
\hline$\%$ Cumulated & 26 & 41 & 51 & 60 & 69 \\
\hline \multicolumn{6}{|l|}{ Coordinates of the modality } \\
\hline \multicolumn{6}{|l|}{ Time } \\
\hline Day 5 & $2 \cdot 22^{*}$ & -0.55 & -0.11 & 0.31 & 0.07 \\
\hline Day 8 & 0.35 & 0.65 & 0.32 & -0.39 & 0.25 \\
\hline Day 15 & $-2 \cdot 57^{*}$ & -0.11 & -0.21 & 0.08 & -0.31 \\
\hline \multicolumn{6}{|l|}{ Factor loading of variables $\ddagger$} \\
\hline Mass of proximal jejunal mucosa & -0.87 & & & & \\
\hline Weight of pancreas & -0.80 & & & & \\
\hline Stomach digestive content & -0.65 & & & & \\
\hline Trypsin activity & -0.61 & & & & \\
\hline Theophylline-induced secretion in proximal jejunum & 0.60 & & & & \\
\hline Crypt depth in ileum & -0.53 & & & & \\
\hline Cholecystokinin plasma concentration & -0.53 & & & & \\
\hline Basal short-circuit current of proximal jejunum & 0.59 & 0.41 & & & \\
\hline Serotonin-induced secretion in proximal jejunum & 0.52 & & -0.48 & & \\
\hline Maltase activity in ileum & & 0.85 & & & \\
\hline Glucose absorption in ileum & & 0.82 & & & \\
\hline Basal resistance of ileum & & -0.66 & -0.36 & & \\
\hline Basal resistance of proximal jejunum & & -0.49 & 0.49 & 0.46 & \\
\hline Villus width in proximal jejunum & -0.51 & & -0.52 & & \\
\hline Villus length in proximal jejunum & -0.55 & & -0.38 & 0.58 & \\
\hline mRNA coding for dipeptidyl-peptidase 4 & & & -0.52 & & -0.64 \\
\hline Amino-peptidase $\mathrm{N}$ activity in proximal jejunum & & & & 0.61 & -0.63 \\
\hline
\end{tabular}

* Indicates that modality was significantly represented by the respective factor $(P<0.05)$.

$\dagger$ Factors or principal components created by PCA are linear combinations of the original variables.

$\ddagger$ Only correlations with $r \geq 0.35$ are indicated. 


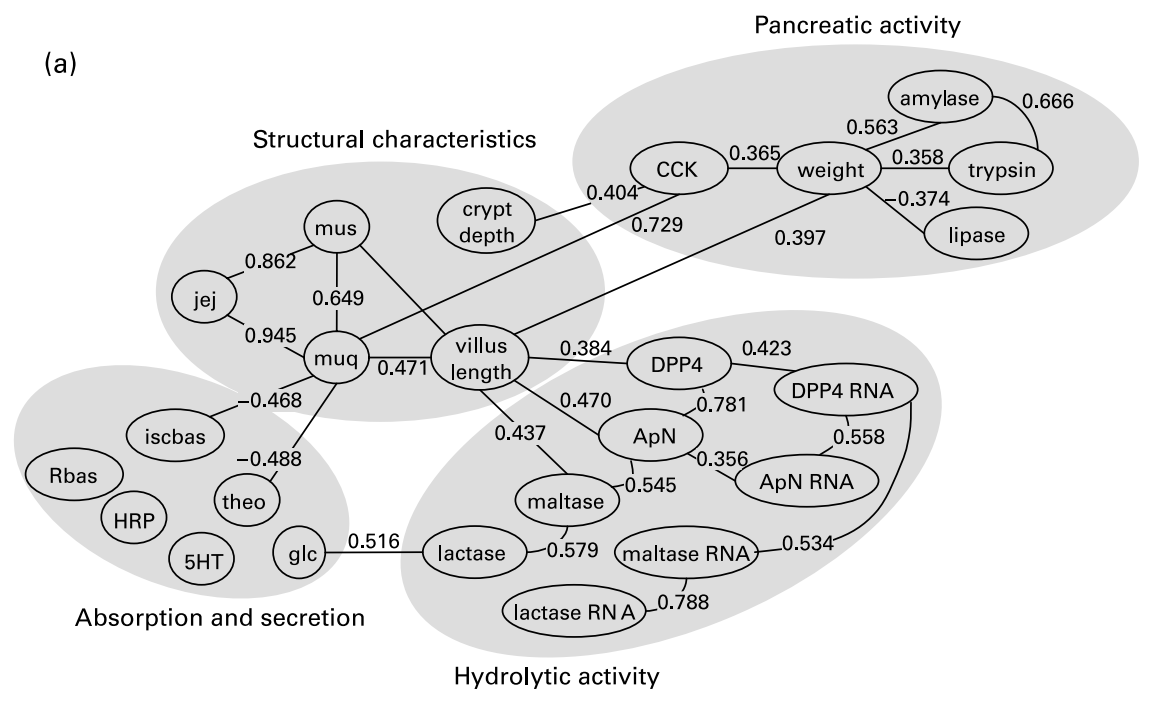

(b)

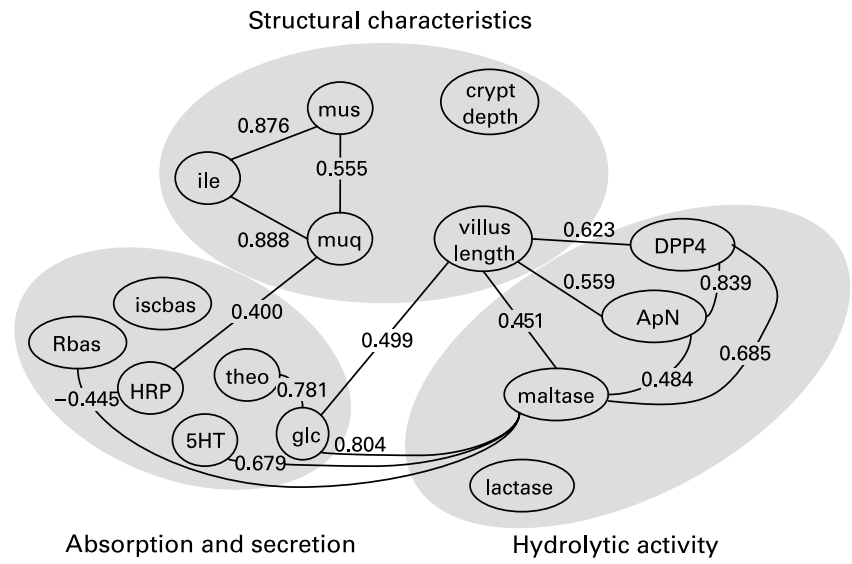

Fig. 1. Correlation coefficients between variables related to structural and functional characteristics of the pancreas and the proximal jejunum (a) and the ileum (b) during adaptation to the weaning diet. ApN, amino-peptidase N; CCK, plasma cholecystokinin; DPP4, dipeptidyl-peptidase 4; glc, glucose absorption; HRP, horseradish peroxidase fluxes across mucosa; $5 \mathrm{HT}$, 5-hydroxytryptamine-induced secretion; ile, mass of distal ileum; iscbas, basal short-circuit current; jej, mass of proximal jejunum; muc, mass of the small intestinal mucosa; mus, mass of the small intestinal muscularis; Rbas, transmucosal resistance. For details of variables, see p. 48. All the reported correlations coefficients were significant $(P<0.05)$.

slaughtered at day 8 from day 15 . It was assumed to represent the time after weaning. The variables represented by factor 1 were the same as in the preceding analysis. Factor 2 explained $16 \%$ of the total variance and was associated with variables measuring the level of lactobacilli and enterococci in colonic digesta ( $r 0.68$ and 0.60$)$ and the $\mathrm{pH}$ of caecal and colonic contents $(r 0.69$ and 0.55$)$, in opposition with enterobacteria $(r-0.49)$. Factor 3 explained $15 \%$ of variability and was associated with variables measuring phenomena occurring mainly in the distal ileal mucosa mainly (similarly to factor 2 in PCA 2). Factor 4 explained $12 \%$ of the variability and was represented mainly by the level of aerobic bacteria in the jejunal contents.

\section{Discussion}

The present results clearly show that temporal changes induced by weaning on the gastrointestinal structure and function can be divided in two: an acute and short time-period, observed from day 1 to day 5 after weaning, followed by a more progressive adaptative and maturational phase, from day 5 to day 15 . In the following sections we propose some markers of phenomena occurring during these two phases post-weaning.

\section{Post-weaning acute phase}

The early phase, from day 0 to day 5 , consisted of an acute deterioration of the gut structure and function, more generally called the gut integrity. This was indicated by decreases in the villous length and in the total brush border enzyme activities, and by an increase in the paracellular permeability (transepithelial resistance), in accordance with earlier observations (Vente-Spreeuwenberg \& Beynen, 2003). Such changes leading to a depressed digestive capacity of the gut have been clearly identified as the main factors predisposing for postweaning digestive disorders in piglets (Hampson, 1994).

The strong correlation between all the changes measured during this acute phase suggested a common cause that was assumed to be the post-weaning fasting period (day 0 to day 2). Indeed, the alterations of the gut integrity were also observed in underfed piglets and in piglets receiving total parenteral 
Table 5. Description of the major factors obtained by principal component analysis (PCA) of seventeen variables characterising gut physiology and microbiology during the adaptative phase post-weaning (twenty-four piglets slaughtered on days 8 and 15 after weaning)

\begin{tabular}{|c|c|c|c|c|c|}
\hline Factors $†$ & 1 & 2 & 3 & 4 & 5 \\
\hline$\%$ Variability explained & 26 & 15 & 10 & 8.9 & $8 \cdot 2$ \\
\hline$\%$ Cumulated & 26 & 41 & 51 & 60 & 69 \\
\hline \multicolumn{6}{|l|}{ Coordinates of the modality } \\
\hline \multicolumn{6}{|l|}{ Time } \\
\hline Day 8 & $1 \cdot 77^{\star}$ & 0.26 & -0.26 & -0.27 & 0.04 \\
\hline Day 15 & $-1.77^{\star}$ & -0.26 & 0.26 & 0.27 & -0.04 \\
\hline \multicolumn{6}{|l|}{ Factor loading of variablesł } \\
\hline Mass of proximal jejunal mucosa & -0.84 & & & & \\
\hline Weight of pancreas & -0.79 & & & & \\
\hline Serotonin-induced secretion in proximal jejunum & 0.47 & & & & \\
\hline Villus width in proximal jejunum & -0.60 & & & 0.57 & \\
\hline Crypt depth in ileum & -0.54 & 0.35 & & & \\
\hline Basal short-circuit current of proximal jejunum & 0.55 & -0.53 & & & \\
\hline Trypsin activity & -0.52 & -0.47 & 0.37 & & \\
\hline Enterobacteria in colonic contents & 0.53 & -0.49 & & -0.50 & \\
\hline Lactobacilli in colonic contents & & 0.68 & & & \\
\hline Enterococci in colonic contents & 0.41 & 0.60 & & & \\
\hline $\mathrm{pH}$ of colonic contents & 0.46 & 0.55 & & & 0.44 \\
\hline $\mathrm{pH}$ of caecal contents & & 0.69 & 0.43 & & 0.41 \\
\hline Maltase activity in ileum & & & 0.81 & & \\
\hline Basal resistance of ileum & & & -0.70 & 0.39 & \\
\hline Glucose absorption in ileum & 0.61 & & 0.65 & & \\
\hline Total aerobic bacteria in jejunal contents & & & & -0.80 & \\
\hline Villus length in proximal jejunum & -0.51 & & & & 0.58 \\
\hline
\end{tabular}

* Indicates that modality was significantly represented by the respective factor $(P<0.05)$.

† Factors or principal components created by PCA are linear combinations of the original variables.

$\ddagger$ Only correlations with $r \geq 0.35$ are indicated.

nutrition, when compared with their counterparts unrestricted or fed with enteral diet, independently of the weaning. In the same way, when feed intake was stimulated at weaning by the use of a liquid instead of a dry diet, smaller improvements of the gut morphology were observed (Deprez et al. 1987; Carey et al. 1994; Park et al. 1998). The effect of fasting (or low feed intake) is most likely multifactorial. It includes a deprivation of luminal substrates for mucosal epithelial cell growth, and a reduced secretion and expression of gut growth factors such as glucagon-like peptide 2, insulin-like growth factor I (Burrin et al. 2000; Stoll et al. 2000; Vente-Spreeuwenberg \& Beynen, 2003) and CCK (present study).

The variables allowing the acute deterioration of the proximal gut structure and function (i.e. villus height, lactase activity and HRP fluxes in the proximal jejunum) as well as plasma CCK to be followed were strongly linked with the factor discriminating piglets at day 0 from piglets at days 2 or 5 (factor 2 of PCA 1; Table 3). Consequently, they could be considered as relevant markers of the post-weaning acute phase. The more the piglets feed intake decreases spontaneously immediately after weaning, the more these markers of gut alteration change and probably the higher is the diarrhoeic risk.

The global analysis also identified a factor (factor 1 of PCA 1; Table 3) that discriminates piglets at day 2 from piglets at day 5 , indicating profound changes in the gut during these $3 \mathrm{~d}$. The variables positively correlated with factor 1 (i.e. $\mathrm{pH}$ of caecal content, pancreatic trypsin activity, theophylline-induced secretion in ileum) were associated with the day 2 post-weaning. They measured the phenomena occurring very transiently at weaning. The lactase specific activity, which dropped in the proximal jejunum between days 2 and 5, was also loaded with factor 1 . The variables negatively correlated with factor 1 , including the glucose absorption capacity in the ileum, were associated with day 5 post-weaning. They measured the phenomena that were not or little affected by the fasting period (days $0-2$ ) but were modified from day 5 . The changes in stomach contents, the weight of stomach and small intestine, and the mass of the proximal jejunal mucosa were probably related to the re-feeding.

The analysis of individual variations of variables demonstrated that the acute effect of weaning was more marked on the proximal part of the small intestine whereas the consequences of fasting were globally less marked and delayed until day 5 in the ileum, as also observed by Burrin et al. (2000) and Vente-Spreeuwenberg et al. (2001). This was confirmed by the global analysis. Indeed, the variables discriminating between days 2 and 5 (linked with factor 1 of PCA 1) concerned the proximal jejunum but also the distal ileum. By contrast, the variables discriminating between days 0 and 2 or 5 (linked with factor 2 of PCA 1) concerned mainly the proximal jejunum. The differential response might be explained firstly by the kinetic of digestion. The arrival of dietary nutrients was stopped earlier in the proximal than in the distal part of the small intestine. It could also result from a difference in the origin of nutrients and especially the amino acids used for mucosal protein synthesis. Amino acids required for the epithelial cell turnover and therefore the maintenance of mucosal integrity can be supplied via the intestinal lumen (first pass) and by the mesenteric artery. In the jejunum, mucosal protein derived more from dietary than from arterial amino acids (Stoll et al. 2000). This was probably exacerbated before weaning because of the high digestibility of sow's milk protein and the fact that hydrolysis and absorption were particularly active in the proximal jejunum when compared to the distal ileum on day 
(Puchal \& Buddington, 1992). By contrast, the distal part of the small intestine probably relies more on arterial amino acids for protein synthesis (Reeds et al. 1999; Stoll et al. 2000) and so was less and only transiently responsive to a decrease in enteral nutrition (Jiang et al. 2000). For the same reasons, as hypothesised by Burrin \& Stoll (2003), the absence of effect of the $2 \mathrm{~d}$ fast on the crypts could be explained by the fact that crypt cells derive their nutrients predominantly from the arterial circulation, whereas villus cells rely mostly on luminal nutrients (Alpers, 1972).

During the acute phase, mRNA coding for the intestinal enzymes were not decreased in contrast with the intestinal enzyme activities. This suggests that fasting affected the post-transcriptional process (lack of amino acids as explained earlier) but did not act on gene expression (Marion et al. 2005). In the pancreas the amounts of protein and enzymes stored in the gland were transiently increased at day 2 . The protein content and enzyme activities measured in the pancreas are the result of both protein synthesis and release via the pancreatic juice. The release of enzymes into the intestinal lumen was lower at day 2 when compared with day 0 , as a consequence of the lack of substrates in the lumen and the decrease of plasmatic CCK. Consequently, the increase of enzymes in the pancreas suggested a transient accumulation, as observed with undernourished baby pigs (Marion et al. 2003). Finally, the capacity of the gut to synthesise enzymes was not suppressed but just transiently depressed by fasting.

\section{Adaptation to the weaning diet}

The late post-weaning phase, from day 5 to day 15 , corresponded to an adaptation of the gut to the weaning diet. The main factors of this adaptation were the re-feeding and the time, while the diet per se had little influence in the present study. The absence or weak influence of the diet composition on gut disturbances at weaning was also observed by several authors (review by Vente-Spreeuwenberg \& Beynen, 2003).

The global analysis by PCA evidenced a first group of variables strongly linked with the factor discriminating between piglets slaughtered at day 5 and at day 15 and therefore representing the time (factor 1 of PCA 2; Table 4). These variables are assumed to be putative markers of the post-weaning refeeding. Amongst these variables were the mass of the proximal jejunum, the weight of the pancreas and the content of the stomach. So the adaptative phase was marked by a partial regeneration of the structural characteristics of the proximal gut. As explained earlier, the re-feeding and consequently the arrival of nutrients in the intestinal lumen was the driving factor for the structural development of the mucosa. The increase in the mass of the jejunum was explained by an increase in the villus length. The villus length was slowly and partially restored but did not return to the pre-weaning level, as also observed by several authors (Kelly et al. 1991; McCracken et al. 1995). The activities of the enzymes of the proximal jejunal mucosa were not restored and stayed at low levels until day 15, although they were significantly correlated with the villus length. The maltase mRNA was increased with time post-weaning, suggesting an enhanced capacity for the enterocytes to synthesise maltase onwards. The pancreatic trypsin activity was also loaded with the factor representing the time. The trypsin activity increased rapidly with time, in correlation with the amylase activity. By contrast, the lipase activity stayed low. These changes in the enzyme activities may be related to the abrupt decrease in the lipid content and the presence of starch in the weaner diets compared to maternal milk (Lindemann et al. 1986; Marion et al. 2003), whereas higher plasma CCK levels favour trypsin synthesis. Finally, the secretagogue-induced secretion was also linked with the factor representing the time. A better capacity of digestion and a lower sensibility to secretagogues may be related to a better resistance of piglets against digestive disturbances.

The global analysis evidenced a second group of variables, comprising the variables measuring the hydrolytic activity, the secretion and absorption of the distal ileum, especially maltase activity, the glucose absorption and the basal resistance. These variables were strongly linked to factor 2 of PCA 2 (Table 4) or factor 3 of PCA 2 (Table 5). Moreover, the variables measuring the bacteria presence, especially lactobacilli and enterococci in colonic contents, and the $\mathrm{pH}$ of colonic and caecal contents, were strongly linked to factor 2 of PCA 3 (Table 5). These variables were probably influenced by factors other than the re-feeding (and therefore are not linked with factor 1). This might reflect a deeper developmental pattern, genetically programmed, that might be initiated by weaning. For example, the glucose absorption capacity, the responses to secretagogue and the basal ileal resistance seem to be profoundly modified at weaning but stay stable after this weaning period throughout the pig's life (Boudry et al. 2004; G Boudry, personal observation). In this way, the adaptative phase corresponded to a period of development and maturation of the distal part of the gut, and variables measuring the functions of the distal ileal mucosa and colonic bacteria might be considered as markers of maturation of the gut.

\section{Conclusions}

From a practical point of view, numerous alternatives to infeed antibiotics for piglets are used in the feed industry. Although some are effective, many others have not yet convinced. In the present work we proposed some biologic markers of post-weaning events. The markers proposed for the acute phase linked to low feed intake are the villus height, the lactase activity and the HRP fluxes in the proximal jejunum, as well as plasma CCK. The markers of events linked with the re-feeding are the mass of the proximal jejunum, the weight of the pancreas, the content of the stomach, the pancreatic trypsin activity and the theophylline-induced secretion in the jejunum. The present work also allows markers to follow the gut maturation induced by weaning to be defined: maltase activity, glucose absorption and basal resistance in the ileum, the lactobacilli and enterococci in the colonic contents, and the $\mathrm{pH}$ of colonic and caecal contents. These markers might help nutritionists to design suitable substances as alternatives to in-feed antibiotics to limit the post-weaning gut disorders by promoting gut maturation.

\section{Acknowledgements}

This paper was partly presented during the $5^{\text {ème }}$ Journées francophones de nutrition, 15-17 December 2004, Lyon, France 
[Montagne L, Boudry G, Lallès JP, Luron I \& Sève B (2004) Etude de l'adaptation de la structure et des fonctions digestives à un aliment post-sevrage par analyse en composantes principales. Nutr Clin Metab 18, Suppl. 1, 67]. The authors gratefully acknowledge all the staff of the UMR SENAH for technical assistance in animal care and chemical analyses. We also thank the staff of the Applied Mathematical Laboratory of Agrocampus Rennes for precious help with statistical analysis. This study was financially supported by the European Union (project Healthypigut contract no. QLK5-CT2000$00522)$ to whom we are grateful. The authors are solely responsible for the work described in this paper, and their opinions are not necessarily those of the European Union.

\section{References}

Alpers DH (1972) Protein synthesis in intestinal mucosa: the effect of route of administration of precursor amino acids. J Clin Invest $\mathbf{5 1}$, $167-173$.

Boudry G, Lallès JP, Malbert CH, Bobiller E \& Sève B (2002) Dietrelated adaptation of the small intestine at weaning in pigs is functional rather than structural. J Pediatr Gastroenterol Nutr 34, $180-187$.

Boudry G, Péron V, Le Huërou-Luron I, Lallès JP \& Sève B (2004) Weaning induces both transient and long-lasting modifications of absorptive, secretory, and barrier properties of piglet intestine. J Nutr 134, 2256-2262.

Brown PJ, Miller BG, Stokes CR, Blazquez NB \& Bourne FJ (1988) Histochemistry of mucins of pig intestinal secretory epithelial cells before and after weaning. J Comp Pathol 98, 313-323.

Bruininx EMAM, Binnendijk GP, van der Peet-Schwering CMC, Schrama JW, Vesseur PC, Everts H, den Hartog LA \& Beynen AC (2001) Individually measured feed intake characteristics and growth performance of group-housed weanling pigs: effect of sex, initial body weight, and body weight distribution within groups. J Anim Sci 79, 301-308.

Burrin D \& Stoll B (2003) Intestinal nutrients requirements in weanling pigs. In Weaning the Pig, Concepts and Consequences, pp. 301-337 [JR Pluske, J Le Dividich and MWA Verstegen, editors]. Wageningen: Wageningen Academic Publisher.

Burrin DG, Stoll B, Jiang R, Chang X, Hartmann B, Holst JJ, Greeley GH \& Reeds PJ (2000) Minimal enteral nutrient requirements for intestinal growth in neonatal piglets: how much is enough? Am J Clin Nutr 71, 1603-1610.

Carey HV, Hayden U \& Tucker KE (1994) Fasting alters basal and stimulated ion transport in piglet jejunum. Am J Physiol 267, $156-163$.

Dalqvist A (1964) Method for assay of intestinal disaccharidases. Anal Biochem 7, 18-25.

David JC, Grongnet JF \& Lallès JP (2000) Weaning affects the expression of heat shock proteins in different regions of the gastrointestinal tract of piglets. J Nutr 132, 2551-2561.

Deprez P, Deroose P, Van den Ende C, Muylle E \& Oyaert W (1987) Liquid versus dry feeding in weaned piglets: the influence on small intestine of early weaned pigs. Am J Vet Res 52, 1743-1746.

Goodlad RA, Levi S, Lee C, Mandir N, Hodgson H \& Wright NA (1991) Morphometry and cell proliferation in endoscopic biopsies: evaluation of a technique. Gastroenterology 101, 1235-1241.

Hampson DJ (1994) Postweaning Escherichia coli diarrhoea in pigs. In Escherichia coli in Domestic Animals and Humans, [CL Gyles, editor]. Wallingford: CAB International.

Hartley HO (1950) The maximum F-ratio as a short cut test for heterogeneity of variance. Biometrika 37, 308-312.

Jiang RX, Chang X, Stoll B, Fan MZ, Arthington J, Weaver E, Campbell J \& Burrin D (2000) Dietary plasma protein reduces small intestinal growth and lamina propria cell density in early weaned pigs. $J$ Nutr 130, 121-126.

Kelly D, Smyth JA \& McCracken KJ (1991) Digestive development of the early weaned pig; effect of continuous nutrient supply on the development of the digestive tract and on changes in digestive enzyme activity during the first weak post-weaning. Br J Nutr 65, 169-180.

Laine J, Beattie M \& LeBel D (1993) Simultaneous kinetic determinations of lipase, chymotrypsin, trypsin, elastase, and amylase on the same microtiter plate. Pancreas 8, 383-386.

Lallès JP, Boudry G, Favier C, Le Floc'h N, Luron I, Montagne L, Oswald I, Pié S, Piel C \& Sève B (2004) Gut function and dysfunction in young pigs: physiology. Anim Res 53, 301-316.

Le Dividich J \& Sève B (2000) Effects of underfeeding during the weaning period on growth, metabolism, and hormonal adjustments in the piglet. Dom Anim Endocrinol 19, 63-74.

Le Huërou I, Wicker C, Guilloteau P, Toullec R \& Puigserver A (1990) Specific regulation of the gene expression of some pancreatic enzymes during postnatal development and weaning in the calf. Biochim Biophys Acta 1048, 257-264.

Lebart L, Morineau A \& Piron M (1995) Chapter 1, section 2. In Statistique Exploratoire Multidimensionnelle, pp. 181-184 Paris: Dunod.

Lindemann MD, Cornelius SG, El Kandelgy SM, Moser RL \& Pettigrew JE (1986) Effect of age, weaning and diet on digestive enzyme level in the piglet. J Anim Sci 62, 1298-1307.

Lopez-Pedrosa JM, Torres MI, Fernandez MI, Rios A \& Gill A (1998) Severe malnutrition alters lipid composition and fatty acid profile on the small intestine in newborn piglets. J Nutr 128, 224-233.

Lowry OH, Rosebrough NJ, Farr AL \& Randall RJ (1951) Protein measurement with the Folin phenol reagent. J Biol Chem 193, $265-275$.

McCracken BA, Gaskins HR, Ruwe-Kaiser KC, Klasing KC \& Jewell DE (1995) Diet-dependent and diet-independent metabolic responses underlie growth stasis of pigs at weaning. J Nutr 125, 2838-2845.

McCracken BA, Spurlock ME, Roos MA, Zuckermann FA \& Gaskins HR (1999) Weaning anorexia may contribute to local inflammation in the piglet small intestine. J Nutr 129, 613-619.

Marion J, Petersen YM, Romé V, Thomas F, Sangild PT, Le Dividich J \& Le Huërou-Luron I (2005) Early weaning stimulates intestinal brush border enzyme activities in piglets, mainly at the posttranscriptional level. J Pediatr Gastroenterol Nutr 41, 401-410.

Marion J, Romé V, Savary G, Thomas F, Le Dividich J \& Le HuërouLuron I (2003) Weaning and feed intake alter pancreatic enzyme activities and corresponding mRNA levels in 7-d-old piglets. J Nutr 133, 362-368.

Miller BG \& Skadhauge E (1997) Effect of weaning in the pig on ileal ion transport measured in vitro. Zentralbl Veterinarmed A 44, 289-299.

Morineau A (1984) Note sur la caractérisation statistique d'une classe et les valeurs-tests. Bull Tech Centre Stat Inform Appl 2, 20-27.

Nuñez MC, Bueno JD, Ayudarte MV, Allmendros A, Rios A, Suarez MD \& Gil A (1996) Dietary restriction induces biochemical and morphological changes in the small intestine of nursing piglets. J Nutr 126, 933-944.

Park YK, Monaco MM \& Donovan SM (1998) Delivery of total parenteral nutrition (TPN) via umbilical catheterization: development of a piglet model to investigate therapies to improve gastrointestinal structure and enzyme activity during TPN. Biol Neonate 73, 295-305.

Petersen YM, Burrin DG \& Sangild PT (2001) GLP-2 has differential effects on small intestine growth and function in fetal and neonatal pigs. Am J Physiol 281, 1986-1993. 
Pié S, Lallès JP, Blazy F, Laffite J, Sève B \& Oswald I (2004) Weaning is associated with an up-regulation of expression of inflammatory cytokines in the intestine of piglets. $J$ Nutr 134, 641-647.

Pierzynowski SG, Weström BR, Erlanson-Albertsson C, Ahren B, Svendsen J \& Karlsson BW (1993) Induction of exocrine pancreas maturation at weaning in young developing pigs. J Pediatr Gastroenterol Nutr 16, 287-293.

Pluske JR, Hampson DJ \& Williams IH (1997) Factors influencing the structure and function of the small intestine in the weaned pig: a review. Livest Prod Sci 51, 215-236.

Pluske JR, Kim JC, McDonald DE, Pethick DW \& Hampson DJ (2001) Non-starch polysaccharides in the diets of young piglets. In Weaner Pig. Nutrition and Management, pp. 81-112 [MA Varley and J Wiseman, editors]. Wallingford: $\mathrm{CAB}$ International.

Puchal AA \& Buddington RK (1992) Postnatal development of monosaccharide transport in pig intestine. Am J Physiol 262, 895-902.

Quemere P, Bertrand G \& Chauvel J (1975) Utilisation comparée de trois céréales (orge, blé, maïs) par le porcelet sevré précocément. In Journées de la Recherche Porcine, pp. 217-222 [Institut Technique du Porc, editor]. Paris: Institut Technique du Porc.
Reeds PJ, Burrin DG, Stoll B \& Vangoudoever JB (1999) Consequences and regulation of gut metabolism. In Proceedings of the VIIIth International Symposium on Protein Metabolism and Nutrition, pp. 127-153 [GE Lobley, A White and JC MacRae, editors]. EAAP Publication no. 96. Wageningen: Wageningen Pers.

Sève B (1994) Alimentation du porc en croissance: integration des concepts de protéines idéales, de disponibilité digestive des acides amines et d'énergie nette. INRA Prod Anim 7, 275-291.

Stoll BX, Chang X, Fan MZ, Reeds PJ \& Burrin DG (2000) Enteral nutrient intake determines the rate of intestinal protein synthesis and accretion in neonatal pigs. Am J Physiol 279, 49-57.

Vente-Spreeuwenberg MAM \& Beynen AC (2003) Diet-mediated modulation of small intestinal integrity in weaned piglets. In Weaning the Pig, Concepts and Consequences, pp. 145-199 [JR Pluske, J Le Dividich and MWA Verstegen, editors]. Wageningen: Wageningen Academic Publisher.

Vente-Spreeuwenberg MAM, Verdonk JMA, Gaskins HR \& Verstengen MWA (2001) Small intestine epithelial barrier function is compromised in pigs with low feed intake at weaning. $J$ Nutr 131, $1520-1527$. 